\title{
ABCC1 wt Allele
}

National Cancer Institute

\section{Source}

National Cancer Institute. ABCC1 wt Allele. NCI Thesaurus. Code C52275.

Human ABCC1 wild-type allele is located in the vicinity of 16p13.1 and is approximately $193 \mathrm{~kb}$ in length. This allele, which encodes multidrug resistance-associated protein 1 , is involved in multispecific organic anion transport. 